\title{
FORUM
}

Submitted 31.07.2017. Approved 09.10.2017.

Evaluated by double blind review process.

Scientific Editors: Cristiane Biazzin, Elyn L. Solano Charris, and Jairo Alberto Jarrín Quintero

DOI: http://dx.doi/10.12660/joscmv10n2p32-43

\section{SOCIAL SUSTAINABILITY IN SUPPLY CHAINS: A FRAMEWORK AND A LATIN AMERICA ILLUS- TRATIVE CASE}

\begin{abstract}
Social issues are under-represented in sustainability, considering historical predominance of economic and environmental issues. This also applies to Sustainable Supply Chain Management. Even with its definition clarified regarding Triple Bottom Line, research still advances disproportionately in environmental and economic dimensions, facing the social dimension. This research aims to analyze how social sustainability is addressed in focal firms and managed into its supply chain. The study explores the concepts of social issues and governance mechanisms, presenting elements discussed in the literature. A framework for managing social sustainability in supply chains is presented, followed by a case to illustrate the discussed concepts in a Latin American context.
\end{abstract}

KEYWORDS | Sustainable supply chain management, sustainability, social sustainability, governance mechanisms, Latin America.

Dafne Oliveira Carlos de Morais

dafne_oliveira@hotmail.com

PhD Candidate at Fundação Getulio Vargas, Escola de Administração de Empresas de São Paulo -

São Paulo - SP, Brazil 


\section{INTRODUCTION}

A growing body of Operation Management's literature began to focus on the integration of socioenvironmental management with Supply Chain Management (SCM), leading to the Sustainable Supply Chain Management (SSCM) field of study. The review of Seuring and Müller (2008) is one of the field's seminal works. The authors proposed the most widespread concept of SSCM, describing it as "the management of material, information and capital flows as well as cooperation among companies along the supply chain while taking goals from all three dimensions of sustainable development, i.e., economic, environmental and social, into account which are derived from customer and stakeholder requirements" (Seuring \& Müller, 2008, p. 1700). The three dimensions refer to the Triple Bottom Line, a management model created by Elkington (1997) to operationalize Sustainable Development's definition. Seuring and Müller (2008) also initiated a call for further research on the social pillar of SSCM, that still echoes.

The lack of progress in the social dimension of SSCM represents a problematic situation. If, on the one hand, it may mean that companies find it much more difficult to identify and to develop practices in social sustainability than in environmental sustainability (Marshall et al., 2015), on the other hand, it may give the impression that sustainability, in its conceptual Triple Bottom Line (TBL) form, is only a theoretical construction with limited relevance (Brandenburg et al., 2014). This omission may also represent that social elements are particularly difficult to achieve or are less tangible when compared to environmental ones (Ashby et al., 2012).

Several reviews of the literature reinforce the social sustainability gap (Carter \& Easton, 2011; Ashby et al., 2012; Marques \& Cousins, 2013; Taticchi et al., 2013; Ahi \& Searcy, 2015; Beske et al., 2015; Touboulic \& Walker, 2015). Considering this context, this study seeks to analyze "How social sustainability is addressed in focal firms and managed into its supply chain?". To guide this research question, the study explores two essential concepts, social issues and governance mechanisms, and provides an illustrative case that explains these concepts in a Latin America context.

The focus on focal firms is indicated due to its leadership role in the supply chain and also for its need to answer society's pressure to adopt sustainable practices (Cooper \& Ellram, 1993; Seuring \& Müller, 2008; Silvestre, 2015). In turn, the focus on a Latin America context addresses the need for new empirical evidences and theoretical reflections outside supply chains from developed economies, the main field explored so far (Silvestre, 2015). In fact, studies investigating contexts of countries such as Brazil, an emerging economy, are highly recommended, once those environments represent a setting of vulnerabilities and demand more effort to adopt SSCM (Busse, 2016).

This study contributes to the SSCM literature by replying to the often calls to approach social sustainability in supply chains and adding a focus on Latin America, a context that also lacks of proper research in the subject. In a conceptual domain, the paper compiles the main literature findings and proposes a framework regarding the managerial practices related to the social dimension of sustainability, along the supply chain. In an empirical domain, it presents the main social issues and governance mechanisms adopted in a context of Latin America. The study represents an initial but important step towards deepening the knowledge on how focal firms from Latin America can address social sustainability along its supply chains. By overcoming the hurdle of address sustainability in its TBL form, companies from Latin America can create new strategies to manage its supply chains and create more value to its stakeholders.

The paper is divided into four topics besides this introduction. The first and the second topics discuss the main concepts of this study, social sustainability and governance mechanisms, considering its different approaches and perspective in SSCM. The third topic presents the elements that compose social issues, governance mechanisms and supply chain actors to create a framework to support the management of social sustainability along the supply chain. Also, an illustrative case is presented to discuss those concepts in a Latin American context. Lastly, the final considerations present and discuss research challenges and gaps related to social sustainability and its governance mechanisms in the SSCM. The paper also brings insights for future research on this important but yet overlooked topic.

\section{SOCIAL SUSTAINABILITY IN SUPPLY CHAINS}

Supply Chain Social Sustainability (SCSS) is understood as addressing social issues upstream and down- 
stream of the focal company, going beyond internal operations to suppliers and stakeholders, such as the local community, society and consumers (Mani et al., 2015). Klassen and Vereecke (2012) highlight three points to manage social sustainability in supply chains: what; who and how. The "what" is related to social issues, the "who" is related to the stakeholders, and the "how" relates to practices adopted to extend sustainability along the supply chain, assumed here as governance mechanisms.

A variety of understandings has been considered for addressing social issues, the "what". In the definition of Klassen and Vereecke (2012, p. 103), for example, social issues in supply chains are the "aspects related to products or processes that affect human security, well-being and community development". In a broader definition (Chardine-Baumann \& Bot-
ta-Genoulaz, 2011), social issues include: social conditions of work (employment, respect for social dialogue, health and safety, development of human resources); human rights (child and forced labor, freedom of association, discrimination); social commitment (involvement in the local community, education, culture and technological development, job creation, healthcare, social investment); customer issues (marketing and information, health and safety, protection of privacy, access to essential services); and business practices (fight against corruption, fair trade and promotion of social responsibility in the influence sphere).

Social sustainability has not yet reached a consensual understanding. Some contents already associated with social issues are presented in Table 1.

Table 1: Social Issues on SCM

\begin{tabular}{|c|c|c|}
\hline Social Issues & Description & Authors \\
\hline Working Conditions & $\begin{array}{l}\text { Employee's working conditions include respect for } \\
\text { social dialogue, development of human resources; } \\
\text { wages, working hours, the right to form unions, } \\
\text { employment contract and worker exploitation }\end{array}$ & $\begin{array}{c}\text { Carter and Jennings (2002); Jorgensen } \\
\text { (2008), Preuss (2009), Park-Poaps and } \\
\text { Rees (2010), Chardine-Baumann and } \\
\text { Botta-Genoulaz (2011), Klassen and } \\
\text { Vereecke (2012); Simões (2014); Dubey et } \\
\text { al., (2016) }\end{array}$ \\
\hline Society & $\begin{array}{l}\text { Considers elements such as corruption, support } \\
\text { in actions for society (e.g., job creation, invest- } \\
\text { ments in R\&D, culture, technology, infrastructure, } \\
\text { support to local suppliers); education programs; } \\
\text { acceptance (e.g., communication channels). }\end{array}$ & $\begin{array}{l}\text { Jorgensen (2008); Chardine-Baumann e } \\
\text { Botta-Genoulaz (2011); Simões (2014); } \\
\text { Ahi e Searcy (2015) }\end{array}$ \\
\hline Product Responsibility & $\begin{array}{l}\text { Integrates consumer health and safety concerns } \\
\text { into the product; information on product, ingre- } \\
\text { dients, origin, use, potential hazards and side } \\
\text { effects, with labeling. Marketing communication, } \\
\text { with ethical guidelines for ads. }\end{array}$ & $\begin{array}{c}\text { Jorgensen (2008), Chardine-Baumann } \\
\text { and Botta-Genoulaz (2011); Simões } \\
\text { (2014). }\end{array}$ \\
\hline Human Rights & $\begin{array}{l}\text { Rights inherent to all human beings, regardless } \\
\text { of nationality, place of residence, sex, national or } \\
\text { ethnic origin, color, religion, language. The right } \\
\text { to equal rights, without discrimination and with } \\
\text { freedom of association, is its core. }\end{array}$ & $\begin{array}{l}\text { Carter and Jennings (2002), Jorgensen } \\
\text { (2008), Mena et al. (2010); Preuss and } \\
\text { Brown (2012); Simões (2014); Dubey et al., } \\
\text { (2016); Mani et al. (2016) }\end{array}$ \\
\hline Ethic & $\begin{array}{l}\text { A team, department or division is responsible for } \\
\text { ethical compliance in manufacturing facilities; } \\
\text { establishes transparent, comprehensive and rigor- } \\
\text { ous codes of ethical conduct; audits clients and } \\
\text { suppliers for compliance with the code. }\end{array}$ & $\begin{array}{l}\text { Carter and Jennings (2002); Dubey et al., } \\
\text { (2016); Mani et al. (2016) }\end{array}$ \\
\hline
\end{tabular}




\begin{tabular}{|c|c|c|}
\hline Health and Wellbeing & $\begin{array}{l}\text { Audits suppliers and guarantees adhesion of oc- } \\
\text { cupational health policy; Ensures women safety } \\
\text { and availability of minimum health care in sup- } \\
\text { plier facilities }\end{array}$ & $\begin{array}{l}\text { Hutchins and Sutherland (2008); Klassen } \\
\text { and Vereecke (2012); Simões (2014); Mani } \\
\text { et al. (2016) }\end{array}$ \\
\hline Equity & $\begin{array}{l}\text { Ensures diversity in in the workplace at customer } \\
\text { and suppliers locations and compliance with gen- } \\
\text { der and non-discrimination policies at customer } \\
\text { and supplier sites. }\end{array}$ & $\begin{array}{l}\text { Carter and Jennings (2002); Hutchins and } \\
\text { Sutherland (2008); Simões (2014); Mani et } \\
\text { al. (2016) }\end{array}$ \\
\hline Philanthropy & $\begin{array}{l}\text { Includes practices such as: donations to NGOs, } \\
\text { encouragement for employees to volunteer and } \\
\text { donate to NGOs; encourage suppliers in philan- } \\
\text { thropic activities, conduct health-related fields for } \\
\text { society involving factory facilities }\end{array}$ & $\begin{array}{l}\text { Carter and Jennings (2002); Mani et al. } \\
\qquad(2016)\end{array}$ \\
\hline Health and Safety & $\begin{array}{l}\text { It includes physical and mental health that is } \\
\text { directly related to safety and hygiene at work. } \\
\text { It also describes hazardous working conditions, } \\
\text { which could leave long-term effects on a worker's } \\
\text { personal health. }\end{array}$ & $\begin{array}{l}\text { Carter and Jennings (2002), Jorgensen and } \\
\text { Knudsen (2006), Hutchins and Sutherland } \\
\text { (2008); Ciliberti et al. (2009), Klassen and } \\
\text { Vereecke (2012); Simões (2014); Dubey et } \\
\text { al., (2016); Mani et al. (2016) }\end{array}$ \\
\hline Child Labor & $\begin{array}{l}\text { It is concerned with work by children under the } \\
\text { age of } 15 \text { which prevents school attendance and } \\
\text { work by children under } 18 \text { years of age that is } \\
\text { dangerous to physical or mental health. }\end{array}$ & $\begin{array}{l}\text { Kolk and Van Tulder (2002); Nadvi (2008); } \\
\text { Zutshi et al. (2009), Lund-Thomsen et al. } \\
\text { (2012) }\end{array}$ \\
\hline $\begin{array}{c}\text { Development of Minori- } \\
\text { ties }\end{array}$ & $\begin{array}{l}\text { Development of populations that are considered } \\
\text { minorities in terms of population by virtue of their } \\
\text { religion, race or ethnicity. }\end{array}$ & $\begin{array}{l}\text { Krause et al. (1999), Carter and Jennings } \\
\text { (2002); Maignan et al. (2002); Carter } \\
\text { (2006), }\end{array}$ \\
\hline $\begin{array}{l}\text { Disabled/ Marginalized } \\
\text { Inclusion }\end{array}$ & $\begin{array}{l}\text { Groups that are mostly neglected in societies for } \\
\text { physical disabilities or those neglected by the gov- } \\
\text { ernment. Population living below the poverty line } \\
\text { is considered as marginalized. }\end{array}$ & $\begin{array}{l}\text { Carter and Jennings (2002); Carter and } \\
\text { Jennings (2004), Hall and Matos (2010) }\end{array}$ \\
\hline $\begin{array}{l}\text { Training Education and } \\
\text { Personal Skills }\end{array}$ & $\begin{array}{l}\text { It assesses the level of commitment to improving } \\
\text { human capital skills and attempts to correlate the } \\
\text { intellectual development of human resources and } \\
\text { social progress achieved by the company. }\end{array}$ & $\begin{array}{l}\text { Hutchins and Sutherland (2008); Simões } \\
\qquad \text { (2014). }\end{array}$ \\
\hline Gender & $\begin{array}{l}\text { Equal treatment of women and transgender, with } \\
\text { equal rights in the workplace }\end{array}$ & $\begin{array}{l}\text { Tallontire et al. (2005), Preito-Carron } \\
\text { (2008), Barrientos (2008) }\end{array}$ \\
\hline Community & $\begin{array}{l}\text { Supports with financial and material resources to } \\
\text { benefit local communities. It focuses on cultural } \\
\text { and educational interactions to improve the exter- } \\
\text { nal social environment around the company. }\end{array}$ & $\begin{array}{l}\text { Carter and Jennings (2002); Ashby et al., } \\
\text { (2012); Simões (2014); Dubey et al., (2016) }\end{array}$ \\
\hline
\end{tabular}

Source: Jorgensen (2008), Simões (2014), Yawar and Seuring (2015) e Mani et al. (2016)

Some authors, such as Jorgensen (2008) and Simões (2014), link social issues with life cycle analysis in order to follow Social Life Cycle Assessment (SLCA). Under this perspective, social issues are divided into four categories of impact (i.e., human rights, labor practices and decent work conditions, society, and product responsibility). These categories are final in- dicators composed by other intermediate indicators, as follows: (1) for human rights, there are intermediate indicators such as non-discrimination (e.g. indicators of diversity); freedom of association and collective bargaining; child labor, including hazardous child labor; and forced and compulsory labor; (2) for work practices and conditions of decent work, one 
has salary; benefits; physical working conditions; psychological conditions of work; work environment; and training and education of employees; (3) for society, there are incidents of corruption; support for development and actions for society; acceptance in the local community; finally, (4) for product responsibility, we have integration of consumer health and safety concerns into the product; product information for users; marketing communications.

In a second approach, Yawar and Seuring (2015) performed a systematic literature review and classified seven major groups of social issues: working conditions; child labor; human rights; health and safety; development of minorities; inclusion of disabled or marginalized persons; and gender. In their survey, they also identified responsible actions in supply chains, aligned in three strategies: the communication strategy, with reporting and labelling actions; compliance with standards/codes of conduct, auditing and monitoring actions; and development of suppliers, with actions of direct development of suppliers; indirect development of suppliers; trust and collaborative relationships. Such strategies would be under the "how", pointed out by Klassen and Vereecke (2012). The "who" point was also addressed by Yawar and Seuring (2015), that divided social issues into demands from internal and external stakeholders.

Mani et al. (2015) and Mani et al. (2016) also developed an approach of social issues with the three points of Klassen and Vereecke (2012). For "what", Mani et al. (2016) developed and validated a scale of social sustainability, applied with managers from India and focused on countries of emerging economies. In their findings, the authors consider six major groups of social issues: philanthropy, security, equity, health and well-being; ethics and human rights, described in Table 1. For "who" and "how", Mani et al. (2015) somehow integrated the "who" and "how" and classified social practices into four phases: supplier relationship phase; internal operations phase; relationship with society's phase and relationship with consumer's phase.

\section{GOVERNANCE MECHANISMS FOR SSCM}

To extend sustainability throughout its supply chain, focal companies can implement different management practices. The practices used to manage the firm's relationships are referred to in the literature as governance mechanisms. In a more focused view, Gimenez and Sierra (2013, p. 191) understand as governance mechanisms "the practices used by companies to manage relationships with their suppliers, with the aim of improving their sustainability performance". In an extended definition, Formentini and Taticchi (2016, p. 1921) describe governance mechanisms as "practices, initiatives and processes used by the focal company to manage relationships with 1) internal functions and departments, and 2) their chain members and stakeholders with the goal of successfully implementing their corporate sustainability approach". Thus, internal control mechanisms are actions limited to corporate limits, while external governance mechanisms, are actions extended at the supply chain level. The mechanisms for extending sustainability to suppliers are increasingly adopted, but the scope and mode of implementation vary significantly (Rao, 2002).

Governance mechanisms have been considered in the literature from four different perspectives (Gimenez \& Sierra, 2013): analysis of the global value chain; social network theory; new institutional economics (such as Transaction Costs Theory); and supply chain management. The role of governance from a SSCM perspective is receiving growing attention from scholars and practitioners (Formentini \& Taticchi 2016). This perspective is assumed in other studies in the area (Gimenez \& Tachizawa, 2012; Gimenez \& Sierra, 2013; Formentini \& Taticchi 2016).

Table 2 presents a compilation of governance mechanisms considered to extend the sustainability of the focal firm into its supply chain. These mechanisms can be divided into integration activities and internal governance; screening/selection of future suppliers; incentive actions for improvement; assessment; monitoring; collaboration and development of suppliers. 
Table 2: SSCM Governance Mechanisms

\begin{tabular}{|c|c|c|}
\hline Governance Mechanisms & Description & Authors \\
\hline $\begin{array}{l}\text { Integration Activities and } \\
\text { Internal Governance }\end{array}$ & $\begin{array}{l}\text { Include: top management support; } \\
\text { codes of conduct/ethics, guides and } \\
\text { internal policies; goals, action plans } \\
\text { and management systems; incentive } \\
\text { systems and for internal members; } \\
\text { supply chain systematic analysis, } \\
\text { with suppliers classification; adhere } \\
\text { to international initiatives (e.g. } \\
\text { Global Compact); Certifications (e.g. } \\
\text { ISO14001) }\end{array}$ & $\begin{array}{l}\text { Bowen et al. (2001); Carter and Jennings (2004); } \\
\text { Handfield et al. (2005); Mamic (2005); Pedersen } \\
\text { and Andersen (2006); Ciliberti et al. (2009) An- } \\
\text { dersen and Skjoett-Larsen (2009); Pagell and Wu } \\
\text { (2009); Tulder et al. (2009); Foerstl et al. (2010); } \\
\text { Goebel et al. (2012); Hoejmose and Adrien-Kirby } \\
\text { (2012) e Harms et al. (2013); Formentini and } \\
\text { Taticchi (2016) }\end{array}$ \\
\hline $\begin{array}{l}\text { Screening/selection of } \\
\text { future suppliers }\end{array}$ & $\begin{array}{l}\text { Definition of minimum standards } \\
\text { required; Process defined for sup- } \\
\quad \text { plier selection }\end{array}$ & $\begin{array}{l}\text { Bowen et al. (2001); Min and Galle (2001); Carter } \\
\text { and Jennings (2004); Mamic (2005); Vachon and } \\
\text { Klassen (2006); Beske et al. (2008); Leire e Mont } \\
\text { (2010); Ehrgott et al (2010); Harms et al. (2013) }\end{array}$ \\
\hline $\begin{array}{l}\text { Incentive actions for } \\
\text { improvement }\end{array}$ & $\begin{array}{l}\text { Establishment of consequences for } \\
\text { non-compliance; Contracts with re- } \\
\text { ward system; Encouraging competi- } \\
\text { tion based on sustainable criteria }\end{array}$ & $\begin{array}{l}\text { Krause et al. (2000); Mamic (2005); Vachon and } \\
\text { Klassen (2006); Andersen and Skjoett-Larsen } \\
\text { (2009); Leire and Mont (2010); Gimenez and Si- } \\
\text { erra (2012); Gimenez and Sierra (2013); Formen- } \\
\text { tini and Taticchi (2016) }\end{array}$ \\
\hline Assessment & $\begin{array}{l}\text { Activities related to supplier assess- } \\
\text { ment, such as application question- } \\
\text { naires or company visit. }\end{array}$ & $\begin{array}{l}\text { Handfield et al. (2005); Leire and Mont (2010); } \\
\text { Gimenez and Sierra (2012); Gimenez and Sierra } \\
\text { (2013); Harms et al. (2013); Sancha et al., (2016) }\end{array}$ \\
\hline Monitoring & $\begin{array}{l}\text { Seeks to guarantee expectations, } \\
\text { with audits or certification by an in- } \\
\text { dependent third party. It reports on } \\
\text { success and how agreed practices } \\
\text { are implemented. }\end{array}$ & $\begin{array}{l}\text { Mamic (2005); Handfield et al. (2005); Vachon e } \\
\text { Klassen (2006); Carter and Rogers, 2008; Away- } \\
\text { sheh and Klassen (2010); Leire and Mont (2010); } \\
\text { Grosvold, Hoejmose and Roehrich (2014); Mar- } \\
\text { shall et al. (2015) }\end{array}$ \\
\hline Collaboration & $\begin{array}{l}\text { Coordination with customers, sup- } \\
\text { pliers and stakeholders to jointly } \\
\text { improve results. May involve: NGOs } \\
\text { membership/collaboration; Collec- } \\
\quad \text { tive initiatives (sectoral) }\end{array}$ & $\begin{array}{l}\text { Bakker and Nijhof (2002); Seuring (2004); Mamic } \\
\text { (2005); Pagell and Wu (2009); Foerstl et al. (2010); } \\
\text { Leire and Mont (2010); Peters et al. (2011); Wu et } \\
\text { al. (2012); Gimenez and Sierra (2013); Marshall et } \\
\text { al. (2015); Sancha et al. (2016) }\end{array}$ \\
\hline Development & $\begin{array}{l}\text { Training and education; Joint } \\
\text { development; Follow-up activities; } \\
\text { Supplier diversity; Knowledge and } \\
\text { shared assets; Knowledge transfer; } \\
\text { Local Suppliers }\end{array}$ & $\begin{array}{l}\text { Bowen et al. (2001); Carter and Jennings (2002); } \\
\text { Maignan et al. (2002); Mamic (2005); Vachon and } \\
\text { Klassen (2006); Krause et al. (2007); Ciliberti et } \\
\text { al. (2008); Pagell and Wu (2009); Leire and Mont } \\
\text { (2010); Gimenez and Sierra (2012); Wu et al. } \\
\text { (2012); Formentini and Taticchi (2016) }\end{array}$ \\
\hline
\end{tabular}

Source: Akhavan and Beckmann (2016), Formentini and Taticchi (2016) Gimenez and Sierra (2013) 
Sustainable initiatives would then be moved along the supply chain through governance mechanisms (Mani et al., 2015) and, in this context, the interest in implementing sustainable initiatives should be combined with the interest in governance models to extend them along the supply chains (Vurro et al., 2009). Sustainable Supply Chain Governance (SSCG) studies are recent but have already highlighted important factors such as the formalization of mechanisms (Alvarez et al., 2010) and the role of collaborative approaches (Vurro et al., 2009).

\section{SOCIAL SUSTAINABILITY IN SUPPLY CHAIN MANAGEMENT: FRAMEWORK AND ILLUSTRATIVE CASE FROM LAT- IN AMERICA}

Figure 1 was elaborated from Klassen and Vereecke (2012) classification of three main points to manage social sustainability in supply chains (i.e., "what", "how" and "who"). The indication of "who" is characterized by the actors that constitute the supply chain (i.e., focal company, first and second tier suppliers, client and end customer), plus local community, society, government and NGOs, prominent stake- holders in the SSCM literature. The "how" relates to governance mechanisms to manage relationships in internal functions, supply chain members and other stakeholders with a view to adopt sustainability (Formentini \& Taticchi, 2016).

The governance mechanisms identified are: integration activities and internal governance; screening/selection of suppliers; incentive actions for improvement; assessment; monitoring; collaboration; development (Gimenez \& Sierra, 2013; Akhavan \& Beckmann, 2016; Formentini \& Taticchi, 2016). Finally, "what" refers to social issues mentioned when addressing social sustainability in supply chains. The social issues identified in the literature are: child labor; work conditions; health and safety; health and wellness; gender; equity; development of minorities; inclusion of marginalized persons; ethic; human rights; philanthropy; product responsibility; community; and society. It is emphasized that references to community and society were referred in the literature both as stakeholders ("who") and as social issues ("what"), which may indicate the complexity of inserting such actors in the SSCM, represented as subjects that interact with the focal company and as targets of management practices.

Figure 1: Framework for Social Sustainability in SCM

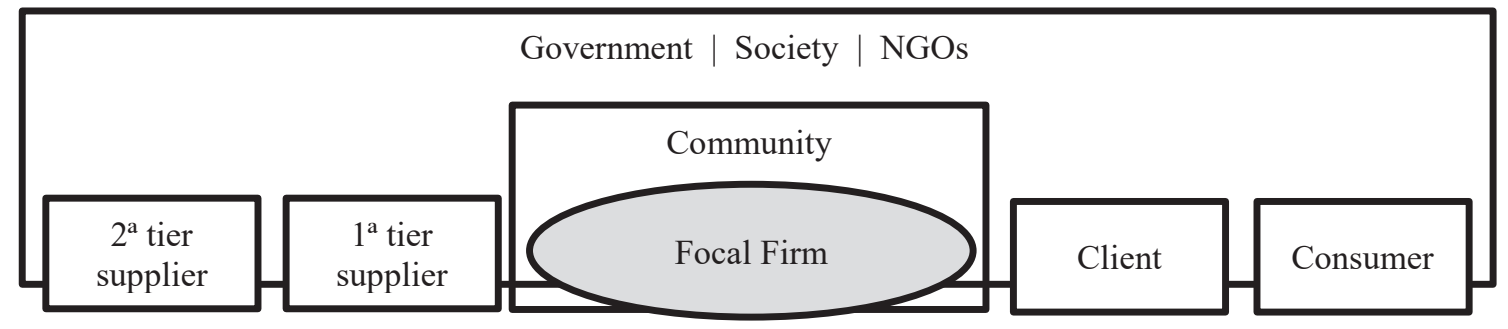

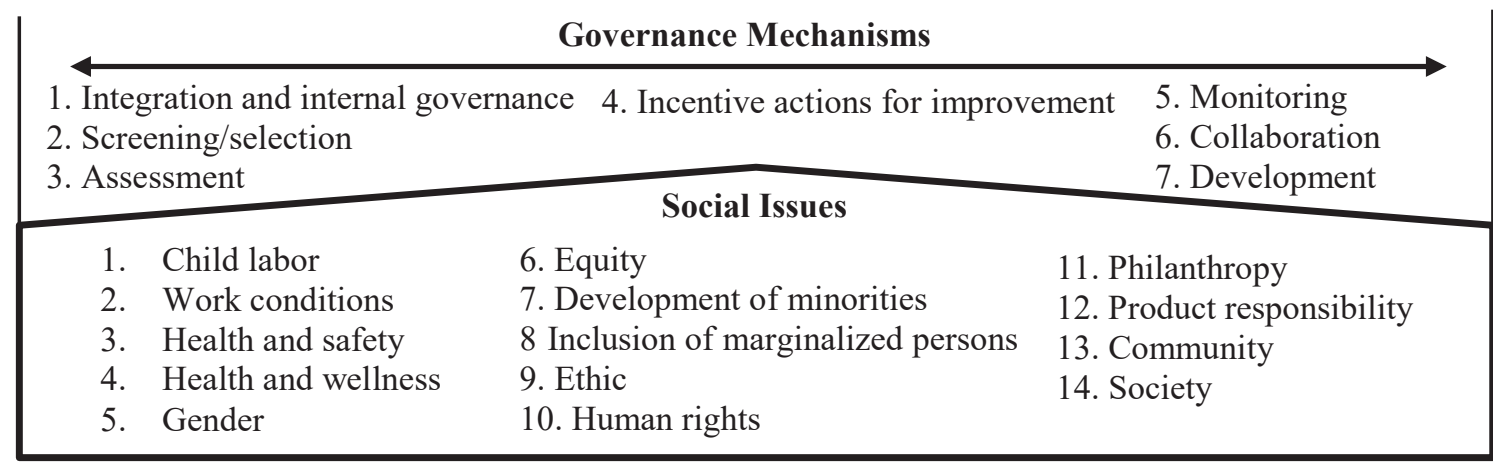

A case to illustrate how social issues can be extended along the supply chain, following the elements exposed in the figure above, is explored based on the initiatives of a multinational company from the food sector. As consumers are becoming more concerned with the products they consume, the food industry seems to be under distinctive scrutiny of the public for a while (Beske, Land, \& Seuring, 2014). Also, this 
industry is relevant for investigating SSCM, since its early stages involves a series of sustainable issues such as product safety and traceability, working conditions, environmental protection. The company investigated states as its propose "to feed the world in a responsible safety and sustainable manner", therefore, it is assumed that it adopts sustainability as a core element of its business strategy, and, thus, with the potential to develop sustainable practices at the supply chain level.

The company has presence in 70 countries. In Brazil, with headquarters based on São Paulo, the company operates in 15 States, through 18 factories and 8,500 employees. The company has completed 50 years in
Brazil and declares to implement a series of sustainable initiatives, internally and along its supply chain. These initiatives were disclosure in the company annual reports and also an interview with its sustainable manager provided information on the process of sustainability management in supply chain.

The data provided was compiled and is presented in Table 3 and represents findings of an illustrative case focused on how to manage social issues along the supply chain. As initial findings, it is possible to identify a concentration of initiatives related to governance mechanisms of integration and internal governance, as well as collaboration and development.

Table 3: Initiatives for Social Sustainability in SCM

\begin{tabular}{|c|c|c|c|}
\hline \multirow[b]{2}{*}{ Initiatives } & \multicolumn{3}{|c|}{ Social sustainability in SCM } \\
\hline & $\begin{array}{l}\text { Who } \\
\text { Supply Chain } \\
\text { Interaction }\end{array}$ & $\begin{array}{l}\text { How } \\
\text { Governance } \\
\text { Mechanism }\end{array}$ & $\begin{array}{c}\text { What } \\
\text { Social Issues }\end{array}$ \\
\hline $\begin{array}{l}\text { Adhere to international initiatives like National } \\
\text { Pact to Eradicate Slave Labor and National Pact } \\
\text { to Eradicate Children and Adolescent Sexual } \\
\text { Exploitation }\end{array}$ & NGOs Society & $\begin{array}{c}\text { Integration and } \\
\text { internal governance }\end{array}$ & $\begin{array}{c}\text { Work conditions } \\
\text { Health and wellness }\end{array}$ \\
\hline $\begin{array}{l}\text { Working Woman Who Breastfeeds: initiative } \\
\text { awarded by the Ministry of Health in recognition of } \\
\text { the offer of maternity leave of six months, day-care } \\
\text { assistance or nursery in the workplace and support } \\
\text { room for breastfeeding }\end{array}$ & $\begin{array}{l}\text { Focal firm female } \\
\text { employees }\end{array}$ & $\begin{array}{c}\text { Integration and } \\
\text { internal governance }\end{array}$ & $\begin{array}{c}\text { Work conditions } \\
\text { Health and wellness } \\
\text { Gender }\end{array}$ \\
\hline $\begin{array}{l}\text { Sustainability Committee: the president and } \\
\text { nine leaders have the role of disseminating the } \\
\text { sustainability strategy in other areas. Considers } \\
\text { agricultural practices; health and safety; suppliers. }\end{array}$ & $\begin{array}{l}\text { Focal firm top } \\
\text { management and } \\
\text { employees } \\
\text { Suppliers }\end{array}$ & $\begin{array}{c}\text { Integration and } \\
\text { internal governance }\end{array}$ & $\begin{array}{l}\text { Health and Safety } \\
\text { Community }\end{array}$ \\
\hline Investments in ports infrastructure & $\begin{array}{c}\text { Society } \\
\text { Government }\end{array}$ & Funding & Society \\
\hline $\begin{array}{l}\text { Available communication channels: a phone } \\
\text { number to receive consumers doubts, suggestions, } \\
\text { critics; online codes of conducts to suppliers } \\
\text { and a phone number for denunciations; online } \\
\text { compliance channel for employees. }\end{array}$ & $\begin{array}{l}\text { Consumer } \\
\text { Suppliers } \\
\text { Focal firm } \\
\text { employees }\end{array}$ & Monitoring & $\begin{array}{l}\text { Society } \\
\text { Product } \\
\text { Responsibility } \\
\text { Working Conditions }\end{array}$ \\
\hline
\end{tabular}




\begin{tabular}{|c|c|c|c|}
\hline $\begin{array}{l}\text { Right Hand Program: supports Childhood Brazil } \\
\text { training multipliers to guide drivers and contracted } \\
\text { carriers to combat children and adolescents sexual } \\
\text { exploitation; truck drivers are trained/mentored } \\
\text { and participate in health actions on special dates. }\end{array}$ & $\begin{array}{l}\text { Suppliers } \\
\text { Client (distribution) } \\
\text { Community }\end{array}$ & Development & $\begin{array}{l}\text { Health and wellness } \\
\text { Community } \\
\text { Working Conditions }\end{array}$ \\
\hline $\begin{array}{c}\text { Food safety Actions: apply a Global Food Safety } \\
\text { Policy; has suppliers' quality standards; production } \\
\text { process with label review stage; discuss public } \\
\text { policies and regulation of food labelling. }\end{array}$ & $\begin{array}{l}\text { Suppliers } \\
\text { Consumer } \\
\text { Government }\end{array}$ & $\begin{array}{l}\text { Incentive actions } \\
\text { for improvement } \\
\text { Collaboration }\end{array}$ & $\begin{array}{c}\text { Product } \\
\text { Responsibility }\end{array}$ \\
\hline $\begin{array}{l}\text { From Grain to Grain: qualifies rural family farmers } \\
\text { to improve quality and support vegetables supply } \\
\text { and distribution. Encourage farmers to create } \\
\text { cooperative and submit incentive programs. }\end{array}$ & $\begin{array}{l}\text { Suppliers } \\
\text { Community }\end{array}$ & Development & $\begin{array}{l}\text { Inclusion of } \\
\text { marginalized persons } \\
\text { Product } \\
\text { Responsibility }\end{array}$ \\
\hline $\begin{array}{l}\text { To know to nurture: in partnership with Abring } \\
\text { Foundation, promotes training of community } \\
\text { health agents and School Feeding Council member } \\
\text { to disseminate healthy eating and local foods. }\end{array}$ & $\begin{array}{l}\text { NGOs } \\
\text { Community } \\
\text { Society }\end{array}$ & Collaboration & $\begin{array}{c}\text { Community } \\
\text { Society }\end{array}$ \\
\hline $\begin{array}{l}\text { Inclusion: in partnership with Asdown, promotes } \\
\text { individual care for people with Down Syndrome } \\
\text { and awareness to the benefits of a balanced diet. }\end{array}$ & $\begin{array}{l}\text { NGOs } \\
\text { Community } \\
\text { Society }\end{array}$ & Collaboration & $\begin{array}{c}\text { Community } \\
\text { Society }\end{array}$ \\
\hline $\begin{array}{l}\text { Vegetable garden at Home for the Elderly: a } \\
\text { vegetable garden was planted to improve the food } \\
\text { conditions of elderly and provide a healthier diet. }\end{array}$ & $\begin{array}{l}\text { NGOs } \\
\text { Community } \\
\text { Society }\end{array}$ & Collaboration & $\begin{array}{c}\text { Community } \\
\text { Society }\end{array}$ \\
\hline $\begin{array}{l}\text { Corporate Volunteering: promotes workshops to } \\
\text { train employees (e.g. Interactive board game, to } \\
\text { promote children healthy eating; access to food, } \\
\text { to promote home vegetable gardens; conscious } \\
\text { consumption, to promote recipe that avoids waste) }\end{array}$ & $\begin{array}{l}\text { Focal firm } \\
\text { employees } \\
\text { Community } \\
\text { Society }\end{array}$ & Development & $\begin{array}{l}\text { Philanthropy } \\
\text { Health and wellness } \\
\text { Community } \\
\text { Society }\end{array}$ \\
\hline $\begin{array}{l}\text { More Sustainable Cocoa: promotes generation } \\
\text { of income from cocoa production; monitors } \\
\text { properties promoting actions to recover degraded } \\
\text { areas and comply with environmental legislation }\end{array}$ & $\begin{array}{l}\text { Suppliers } \\
\text { Community } \\
\text { Society }\end{array}$ & $\begin{array}{c}\text { Monitoring } \\
\text { Development }\end{array}$ & $\begin{array}{l}\text { Inclusion of } \\
\text { marginalized persons } \\
\text { Society }\end{array}$ \\
\hline
\end{tabular}

Source: Empirical data

Initiatives undertaken by integration and internal governance were associated with social issues such as work conditions, health and wellness, gender and community and with stakeholders like focal firm's top management and employees, suppliers, NGOs, society. Initiatives carried out through development were associated with social issues like working conditions, health and wellness, the inclusion of margin- alized persons, philanthropy, product responsibility, community and society, and linked to stakeholders like focal firm employees, suppliers, clients (distribution), community and society. As for initiatives realized by means of collaboration, social issues identified were product responsibility, community and society and with stakeholders like NGOs, consumer, government, community and society. 
Other governance mechanisms have been identified, such as monitoring, incentive actions for improvement. Funding could not be related to any of the mechanism recognized in the previous literature. The first, monitoring, dealt with social issues linked with working conditions, product responsibility and society and interact with focal firm employees, suppliers, consumers, community and society. Incentive actions for improvement were accompanying product responsibility and related with suppliers. Funding was assigned with an initiative regarding investments to improve and expand ports infrastructure. This investment was focused on benefits for the own company, but also created positive externalities that benefit society and government, once leaded to job creation, investments in infrastructure and increased transactions and tax payments. More initiatives that fit within this criterion should be identified and analyzed to understand if it really should be considered as a new governance mechanism.

It was possible to observe that implemented social initiatives tend to deal with multiple social issues and multiple stakeholders and sometimes can even be developed through more than one governance mechanisms.

Negotiating sustainable criteria with suppliers seems to be a hurdle in the food industry. According to the sustainability manager,

"Depending on the type of supplier, if I create a barrier, such as 'you will only sell to me if you hand me the $\mathrm{X}$ document or if you have $\mathrm{X}$ percent of women', he will respond to me 'thank you, I will sell to your competitor because he seems to need me more than you".

Thereby, many sustainable issues cannot be managed by one company in isolation, and, as a way out, collaboration and sectorial initiatives might take place. As he states:

"For many years we started this journey, especially with agricultural producers, more than 10 years (...) and one of the convictions that we had, from the beginning, was that we alone would never solve the problem".

"Although we are big, when you do not have the purchasing power necessary to influence the market, you have to work as a group. So, in many of our solutions, we always work with the industry or with as many companies as possible, so that you can make a change that makes some sense (...) So we work with our direct partners, even our direct competitors can be partners of our projects"

This evidences the complexity of extending sustainability along the supply chain, which tends to be developed through synergy initiatives, often depending on the counterpart of other stakeholders as employees (e.g. corporate volunteering), response from suppliers (e.g. production standards) and partnerships (e.g. projects with NGOs).

\section{CONCLUSION}

The present study sought to analyze how social sustainability is addressed in focal firms and managed into its supply chain. To guide this goal, the study was based on two main concepts, social sustainability and governance mechanisms. These concepts were presented and compiled, considering different approaches in the SSCM's literature.

This study brings as contribution a response to the constant calls to approach social sustainability in supply chains. The three points highlighted by Klassen and Vereecke (2012) to manage social sustainability in supply chains (i.e., "who", "how" and "what") were explored and then articulated into a framework. The framework sheds a light on the elements that make up the management of social sustainability in supply chains and represents an initial effort, providing additional explanations with a case that illustrates some of its application's possibilities. The framework adopts a holistic view, which takes into account literature indications (Ashby et al., 2012). According to the authors, much of the studies that address the social dimension tend to focus on a specific area or practice, such as working conditions or human rights, and do not consider the whole perspective.

Also, a case from a company that operates in Latin America was addressed to illustrate how social sustainability can be extended into supply chains in this peculiar context, potentially more vulnerable and challenging (Busse, 2016). As stated previously, the study represents an initial but important step towards deepening the knowledge on how focal firms from Latin America can address social sustainability along its supply chains. By overcoming the hurdle of address sustainability in its TBL form, companies from Latin America can create new strategies to 
manage its supply chains and create more value for its stakeholders.

Additionally, this study indicates as a research direction to investigate the phenomenon of partnerships and sectoral practices as a mechanism for governing relationships with suppliers to implement social issues along the supply chain. Other gaps related to the social side of SSCM are highlighted in the literature. For Meixell and Luoma (2015), future studies should explore aspects about awareness, adoption and implementation of social objectives in the SSCM. Seuring (2013) points to the opportunity to connect studies on the social side of the SSCM with studies on the basis of the pyramid. For Gimenez and Tachizawa (2012), surveys focused primarily on environmental practices and more research based on surveys could explore factors that facilitate the implementation of social practices. For Ahi and Searcy (2015), Tajbakhsh and Hassini (2015) and Taticchi et al. (2013), social issues are mostly neglected in research focused on performance measurement in SSCM. According to these authors, in order to ensure social issues treated in the same way as economic and environmental issues, it would be necessary to develop quantitative metrics in this area, which is not a simple task, since social elements are particularly difficult to achieve and, often less tangible than environmental ones (Ashby et al., 2012). Sancha et al. (2016) also indicate quantitative studies in the area, suggesting the elaboration of a scale that measures social constructs, such as social performance or social practices. It is noteworthy that Mani et al. (2016) validated a scale for social issues in the SSCM, as discussed in a previous topic. The authors proposed six major groups of social issues (i.e., philanthropy, security, equity, health and well-being, ethics and human rights), which could be investigated in the future in order to confirm their application in another context. The present study, considering its systemic perspective and exploratory nature, points out thirteen groups of social issues, described in the first topic and presented in Figure 01. Yawar and Seuring (2015) stimulate research in developing countries, indicating the need to focus studies on impacts on suppliers located in developing countries, where relevant social issues must be addressed. However, it should be emphasized that the local and national contexts in which research is inserted must be characterized and considered in greater detail, since similar contexts may occur in developed countries and in between developing countries. For example, issues of gender and human rights are linked to cultural and legislative aspects. Hence, associating such issues between countries like India, China and Brazil, all developing countries, but with distinct cultures and legislations, can be a superficial analysis. On the other hand, issues of corruption and lack of ethics have already been identified in both developed and developing countries. Considering a theoretical perspective, Touboulic and Walker (2015) suggest that in order to investigate human aspects of SSCM, authors could lend organizational behavior and psychology theories, such as Sensemaking Theory, or even extend well-known theories such as Maslow's hierarchy of needs.

All of these gaps reinforce the need to enhance knowledge in this area of research, a topic needed to bring sustainable supply chains truly into sustainability.

\section{REFERENCES}

Ahi, P., \& Searcy, C. (2015). An analysis of metrics used to measure performance in green and sustainable supply chains. Journal of Cleaner Production, 86, 360-377.

Akhavan, R. M., \& Beckmann, M. (2017). A configuration of sustainable sourcing and supply management strategies. Journal of Purchasing and Supply Management, 23(2), 137-151.

Alvarez, G., Pilbeam, C., \& Wilding, R. (2010). Nestlé Nespresso AAA sustainable quality program: An investigation into the governance dynamics in a multi-stakeholder supply chain network. Supply Chain Management: An International Journal, 15(2), 165-182.

Ashby, A., Leat, M., \& Hudson-Smith, M. (2012). Making connections: A review of supply chain management and sustainability literature. Supply Chain Management: An International Journal, 17(5), 497-516.

Beske-Janssen, P., Johnson, M. P., \& Schaltegger, S. (2015). 20 years of performance measurement in sustainable supply chain management - What has been achieved? Supply Chain Management: An International Journal, 20(6), 664-680.

Brandenburg, M., Govindan, K., Sarkis, J., \& Seuring, S. (2014). Quantitative models for SSCM: Developments and directions. European Journal of Operational Research, 233(2), 299-312.

Busse, C. (2016). Doing well by doing good? The self-interest of buying firms and sustainable suplly chain management. Journal Of Supply Chain Management, 52(2), 1-20.

Carter, C. R., \& Easton, P. L. (2011). SSCM: Evolution and future directions. International Journal of Physical Distribution \& Logistics Management, 41(1), 46-62.

Chardine-Baumann, E., \& Botta-Genoulaz, V. (2011). A framework for sustainable performance assessment of supply chain management practices. International Conference on Computers and Industrial Engineering, 76, 56-61. 
Cooper, M. C., \& Ellram, L. M. (1993). Characteristics of supply chain management and the implications for purchasing and logistics strategy. The International Journal of Logistics Management, 4(2), 13-24.

Formentini, M., \& Taticchi, P. (2016). Corporate sustainability approaches and governance mechanisms in sustainable supply chain management. Journal of Cleaner Production, 112, 1920-1933.

Gimenez, C., \& Sierra, V. (2013). Sustainable supply chains: Governance mechanisms to greening suppliers. Journal of Business Ethics, 116(1), 189-203.

Gimenez, C., \& Tachizawa, E. M. (2012). Extending sustainability to suppliers: A systematic literature review. Supply Chain Management: An International Journal, 17(5), 531-543.

Jørgensen, A., Le Bocq, A., Nazarkina, L., \& Hauschild, M. (2008). Methodologies for social life cycle assessment. International Journal of Life Cycle Assessment, 13(2), 96-103.

Klassen, R. D., \&Vereecke, A. (2012). Social issues in supply chains: Capabilities link responsibility, risk (opportunity), and performance. International Journal of Production Economics, 140(1), 103-115.

Mani, V., Agrawal, R., \& Sharma, V. (2015). Supply chain social sustainability: A comparative case analysis in indian manufacturing industries. Procedia-Social and Behavioral Sciences, 189, 234-251.

Mani, V., Agarwal, R., Gunasekaran, A., Papadopoulos, T., Dubey, R. \& Childe, S. J. (2016). Social sustainability in the supply chain: Construct development and measurement validation. Ecological Indicators, 71, 270-279.

Marques, L., \& Cousins, P. (2013). Sustainability, business and supply chain management: A systematic review of the literature (1960-2009). EurOMA - European Operations Management Association. Retrieved from https://www. researchgate.net/publication/258245164_Sustainability_ business_and_supply_chain_management_a_systematic_ review_of_the_literature_1960-2009.

Marshall, D., McCarthy, L., Heavey, C., \& McGrath, P. (2015). Environmental and social supply chain management sus- tainability practices: Construct development and measurement. Production Planning \& Control, 26(8), 673-690.

Meixell, M. J., \& Luoma, P. (2015). Stakeholder pressure in sustainable supply chain management. International Journal of Physical Distribution \& Logistics Management, 45(1-2), 69-89.

Rao P. (2002), Greening the supply chain: A new initiative in South East Asia. International Journal of Operations and Production Management, 22, 632-655.

Sancha, C., Gimenez, C., \& Sierra, V. (2016). Achieving a socially responsible supply chain through assessment and collaboration. Journal of Cleaner Production, 112(3), 1934-1947.

Seuring, S. (2013). A review of modeling approaches for sustainable supply chain management. Decision support systems, 54(4), 1513-1520.

Seuring, S., \& Müller, M. (2008). From a literature review to a conceptual framework for sustainable supply chain management. Journal of Cleaner Production, 16(15), 1699-1710.

Silvestre, B. S. (2015). Sustainable supply chain management in emerging economies: Environmental turbulence, institutional voids and sustainability trajectories. International Journal of Production Economics, 167, 156-169.

Simões, M. (2014). Social key performance indicators - Assessment in supply chains. Técnico Lisboa. June, pp. 1-10.

Tachizawa, E., \& Wong, C. (2014). Towards a theory of multi-tier sustainable supply chains: A systematic literature review. Supply Chain Management: An International Journal, 19(5-6), 643-663.

Tajbakhsh, A., \& Hassini, E. (2015). Performance measurement of sustainable supply chains: A review and research questions. International Journal of Productivity and Performance Management, 64(6), 744-783.

Taticchi, P., Tonelli, F., \& Pasqualino, R. (2013). Performance measurement of sustainable supply chains. International Journal of Productivity and Performance Management, 62(8), 782-804.

Touboulic, A., \& Walker, H. (2015). Theories in SSCM: A structured literature review. International Journal of Physical Distribution \& Logistics Management, 45(1-2), 16-42. 